\title{
ADRA2B Gene
}

National Cancer Institute

\section{Source}

National Cancer Institute. ADRA2B Gene. NCI Thesaurus. Code C21288.

This gene is involved in transcriptional regulation and G protein-coupled receptor signal transduction. 